\title{
Forty Years of Development Research: Transformations and Reformations
}

\author{
John Humphrey
}

\begin{abstract}
1 Introduction
The theme of this special issue of the IDS Bulletin 'Reinventing Development Research', is doubly immodest. First, as Lawrence Haddad points out (see page 1), devoting a conference and an issue of the IDS Bulletin to this theme assumes that development research is in need of reinvention. Second, the stated mission of IDS, to 'make a difference', implies that any reinvention is not only an intellectual exercise, but also one that will change policy and have an impact on welfare and livelihoods. Nevertheless, the task is made less daunting by the fact that 'development research and development studies' has continually reinvented itself over the past halfcentury. The subject matter, methods and priorities of the 1960s are substantially different from those of the 1990s, for example. New themes and issues are arising all the time.
\end{abstract}

This article addresses the issue of how broad a reinvention of development studies needs to be. It argues that in order to continue to be relevant in the next 40-50 years, two fundamental issues will need to be addressed. First, the basic assumption of the discipline - that there is something specific about developing countries that sets them apart from developed countries - will need to be challenged, if not rejected out of hand. This has implications for the intellectual project of reinvention. Second, the relationship between development and policy, and more particularly, the relationship between development research and aid donors, needs to be critically evaluated. This has implications for the audience and drivers of a reinvention of development research. These issues are explored through a consideration of the origins of development studies and how it has changed in the past 40 years.

\section{The birth of development studies: progress and optimism}

Concerns about economic development, social transformation and 'catching up' long predate anything that could be regarded as development studies. These were the issues that dominated economic policy in the nineteenth century, particularly in those countries trying to cope with the dominance of the British economy. It is worth noting that Friedrich List, the theoriser of long-term national economic development strategies, was a German who developed many of his ideas while working in that other challenger to British power, the USA. In the nineteenth century, the issues of the rise of capitalism, social transformation and national development were central not only to economics, but also the birth of sociology as a discipline and to radical politics. While much social thinking was focused on the origins of industrialisation and its consequences for social and political stability, social theorists were quick to observe and analyse differences between societies. Similarly, it was not long before the assumptions of linear evolution were challenged by analyses that highlighted relationships between societies and the way in which industrialisation in some countries shaped the development conditions and challenges facing others. ${ }^{1}$

If, however, one were to put a date on the birth of development studies, then the two best candidates would be the late 1940s and the decade from the mid-1950s to the mid-1960s. The late 1940s ranks as a candidate for the birth of development studies because it is the time when the Prebisch-Singer hypothesis was developed. This stands in marked contrast to the other key statement of the potential for economic growth made at the same time - the 
factor price equalisation theory (Samuelson). While Samuelson's theory predicted worldwide equalisation of factor prices (including wages) as a result of free trade and the free movement of factors (under some demanding conditions), Prebisch and Singer argued that there were systematic tendencies towards widening income inequality between developed and developing countries, as a result of their specialisation in the production of manufactured goods and agricultural/mineral commodities, respectively. This difference in approach is an enduring one within development research. ${ }^{2}$

The decade from the mid-1950s is a candidate for the origin of development research because of the opening of institutions devoted to development policy and training. Decolonisation in Africa led to the creation of institutions such as the Institute for Development Studies at the University of Nairobi (1965) and the Institute of Development Studies at the University of Sussex (1966). Both were created for the specific purposes of capacity building and policy formulation in support of the post-independence governments of Africa. However, other notable institutions, such as Queen Elizabeth House (Oxford), the Institute for Development Policy and Management (Manchester) and the Institute of Social Studies (The Hague), were all founded in the 1950s. The links between development research, development research institutions and practical development challenges were established right from the start.

The overall perspective that informed both researchers and donors alike at that time can be summarised as four characteristics:

1 The goal of development. The goal of development policy was to achieve modernity. In other words, success for developing countries would be to become more like developed countries. Even critics of orthodox development policy, such as the structuralist school in Latin America that built on the work of Prebisch and later theorists (notably Celso Furtado), did not dispute the outcome. The dispute was about the route through which this outcome could be achieved. Even Marxist or socialist critics would not dispute the importance of industrialisation and urbanisation as representations of progress. ${ }^{3}$

2 Optimism. For mainstream development studies, the goals of industrialisation and modernisation were achievable. Of course, there were theorists who did not share this view. Among those prominent were Franz Fanon, whose critique was one of colonialism rather than underdevelopment (he died in 1961, before the conclusion of the Algerian war of independence in July 1962), and writers who were criticising capitalism in general rather than its impact on developing countries. ${ }^{4}$ In the mid-1960s, mainstream development studies was characterised by a sense of optimism about achieving development and overcoming poverty. This came out very clearly in the Roundtable discussion organised by the Institute for Development Studies in Nairobi. Furthermore, with development and modernisation seen as radically transforming societies (and with elites in developed countries ${ }^{5}$ largely unconcerned about social and regional inequalities in their own countries), economic development was seen as the driver for a broad social transformation: the rising tide of affluence would benefit all.

3 The State. The State was expected to play an active and positive role in promoting development. This view was shared by both mainstream development theorists and dependency critics. In the mid-1960s, developed countries were still strongly influenced by Keynesianism, and the European perspective was informed by the role of the State in postwar reconstruction and economic management, including the Marshall Plan and the development of the European Economic Community. Europe also witnessed the growth of nationalised industries in this period. Transport (railways, airlines, ports, etc.), telecommunications and power supply were predominantly stateowned, as were important parts of manufacturing. Confidence in the positive role of the State was accompanied by optimism about the role of national elites in promoting national development.

4 National development. The fourth element of the development perspective in the mid-1960s was a focus on national development. The unit of analysis for economic planning and management was the nation state. Tariffs were high, with the first significant round of GATT negotiations, the Kennedy Round, not begun until 1962. If newly independent countries wanted proof that statedirected, national development policies could really make a difference, they only had to look westwards to Latin America, where rapid industrial 
development and growth had been achieved in Brazil and Argentina in the 1950s through the adoption of import-substitution policies.

The characteristics of development studies in the mid-1960s have certainly changed. Each of these four elements has been challenged and, in effect, rejected. First, Western modernity is no longer uncritically viewed as the future of developing countries. Even if it were, environmental and resource constraints would make it impossible to achieve on a global scale. Second, optimism has been replaced by a substantial dose of pessimism. In the 1960s and 1970s, this pessimism came from the Left, from the theorists of underdevelopment, who argued that capitalism in the periphery could not perform its historically progressive role. From the 1980 s onwards, it has been much more generalised, partly as a consequence of the continuing prevalence of poverty in Africa, but equally because of the failure of the benefits of economic growth to reach many of the poorest in society. One early and influential recognition of this problem was the work on the informal economy, crystallised in the International Labour Organization (ILO) employment mission to Kenya. It was a recognition that economic growth was not going to render the informal economy obsolete. Specific policies were needed to support it. ${ }^{6}$ Development researchers and donor policy is now much more focused on the ability of economic development to deliver benefits to the poorest, even though this is still a big challenge for Europe and North America as well. ${ }^{7}$ These concerns are also seen in the recognition of multiple sources of persistent inequality and injustice along gender, ethnic and regional lines.

Third, states are under pressure. Instead of being part of the solution (intervening to offset market failures), influential currents of opinion have characterised them as being part of the problem. Finally, the nation state is no longer the only unit of analysis for development policy and practice. On the one hand, sub-national strategies have become more important, with an increasing interest in local economic development and increased concerns about regional inequalities. On the other hand, national development and national development strategies have been undermined by globalisation, particularly vastly increased flows of goods, services and capital (foreign direct investment, portfolio investment and monetary flows). As important, one of the responses to the forces of globalisation has been increased supranational regionalism. Increasing fragmentation of production across national boundaries and a proliferation of regional trade agreements have together put the supranational region at the centre of development initiatives. In this case, developing countries are following in the footsteps of Europe and North America.

This reinvention of development studies and development research might itself seem to be a cause for optimism. The discipline has succeeded in responding to new challenges over the past few decades. Perceptions of the heterogeneity and complexity of poverty and socioeconomic inequality are now much more sophisticated. Similarly, views of whether and how the state can address these challenges are much more varied and critical. However, the nature of these past reinventions needs further examination. The image of reinvention is not as positive as it might appear.

\section{What drives reinventions of development?} One of the main preoccupations around the continuing reinvention of development research has been the extent to which it reflects 'Northern' or 'Southern' agendas and priorities. This issue arises not only because of the inequalities in the resources available to Northern and Southern researchers and research institutions, and the consequences of this for the way that research agendas are defined and developed, but also as a consequence of the increasing role of Northern donors in directing development research. It is not 'Northern agendas' per se that are the main problem, but rather the ability of the controllers of development research finance to occupy research space in both North and South. Any reinvention has to address this issue.

However, when thinking about reinventions, a bigger concern should be the extent to which the major transformations of development thinking have occurred are as a result of broader changes in both political priorities and intellectual debates. They go far beyond either the intellectual debates within development research or the concerns of aid donors. Three seismic shifts in development research in the past four decades have been:

1 Gender. 2006 was also the thirtieth anniversary of UNIFEM. The Voluntary Fund for the UN Decade for Women was established by the UN 
General Assembly in 1976. The IDS conference on the subordination of women in the development process took place two years later. Gender was certainly not on the horizon in 1966. Now it is a central concern in many areas of development research and development policy, even if much still needs to be done. The driver of this change was undoubtedly the feminist movements in Europe and North America and their impact on intellectual life in both continents.

2 Environment. Again, this was not a major concern in 1966, and initial concerns with the environment did not emerge from development studies. The Club of Rome, founded in 1968, was a group of European scientists, businessmen and politicians, and the first UN conference on the human environment took place in Stockholm in 1972

3 Neoliberalism. This was also a big shift for development research and development policy. It arose partly out of the crisis of the Western economies in the 1970s, with the combination of accelerating inflation and economic stagnation, stagflation. Politically, it was put on the agenda for both developed country policy and for developing country policies by Reagan and Thatcher in the early 1980s, although it can be argued that as a reflection of the nonaccountability of development policymaking, the pursuit of the policy agenda was much less circumscribed by political opposition in developed countries than it was in developing countries.

These shifts have had an enormous impact on the subject matter of development studies and on policy priorities. One could take the lesson from these 'reinventions' to be that development studies is a discipline that reacts to and feeds off broader intellectual and political currents that emanate predominantly from the North. The problem of Northern bias is not that Southern voices are weak within development studies, but rather that the reinventions come from outside.

An alternative way of viewing these issues is to accept that thinking on development will always be informed by broader intellectual currents. The three seismic shifts mentioned above had a massive impact right across intellectual thinking and policymaking. Disciplines such as sociology, anthropology and geography have also undergone a transformation in these decades as a result of these changes. The implication is that development research exists within a much larger pool of intellectual and political endeavour. Rather than lamenting a perceived lack of autochthony in development research, one should recognise that autochthony is an illusion for most disciplines. This poses a question for the task of reinvention. How far is reinvention about working within the broader framework of intellectual activity, and how far is it about contributing to changing that framework? If it is the latter, how much does development studies have to engage with much broader agendas and agendasetters than are contained within current development thinking and policy?

\section{Reinventing development research: putting development in its place}

Two challenges were posed at the beginning of this article, and a third issue emerged at the end of the previous section. The issue list for the challenge of reinvention now reads:

1 Is there something specific about developing countries that sets them apart from developed countries?

2 How does reinvention fit into the relationship between development research and aid donors?

3 How far does reinvention need to step outside the boundaries of development studies?

On the first question, it is clear that development studies and development research were products of a particular period and a particular set of challenges - challenges for both the donor countries wanting to support development and for the countries whose development was supposed to be assisted by development research. One can debate the consequences of this origin. What is not open to debate, however, is the fact that the world has changed very radically.

The most significant change is globalisation. Levels of integration are much higher than in the past, so that much development research now involves examining the North, as well as the South. As important, globalising forces are not merely an external context in which national economies operate. For example, the impact of global competition and global regulation on developing countries has deepened as a result of both increasing openness to trade and 
investment and the broadening scope of global governance and the greater depth of its impact on developing country economies and institutions. As a result, the local and the global are more inextricably linked than ever before. For some areas of research, the North-South divide which lay at the origin of development studies is no longer sustainable.

But the new challenge of globalisation is not limited to this. The rise of Asia and the new assertiveness of the fast-growing developing economies is undermining the North-South dichotomy. This goes beyond the issue of 'graduation' - that some countries are no longer 'developing'. South Korea, whose gross domestic product (GDP) in 1966 was similar to many African countries, is now a member of the OECD with a per capita income level equal to that of Portugal in 2004. The 'graduation' issue leads to an increasing donor concentration on sub-Saharan Africa and South Asia, and their gradual withdrawal from Latin America and East Asia. Within the 'multiple Souths', some parts are more important for the donors than others, although not necessarily for development research.

The real challenge of the rise of Asia is actually much greater than this. It concerns the way in which these rapidly growing and potentially very powerful economies affect development prospects and development thinking in the rest of the developing world. As Schmitz (this IDS Bulletin) observes, two large, and until recently, poor economies are beginning to drive economic and political change globally, posing fundamental challenges to development studies. While much of orthodox development thinking assumes the superiority of, or at least the dominance of, the West, the rise of Asia has meant that countries that are still relatively poor are having a substantial impact on global economy, global governance and (in the near future) development policy and practice. ${ }^{8}$ Perhaps for the first time, we are seeing Southern policy agendas that are backed up by financial muscle (e.g. China's expanding aid and investment programme), the credibility that goes with rapid growth, and the intellectual and policymaking capacity to shape global agendas. This is certainly a challenge for the reinvention of development studies. There are both new programmes and priorities, and also new actors whose interests have to be addressed and incorporated as the world struggles to produce global public goods such as financial stability, sustainable energy use, responses to climate change and security. In each area, what the global public good really is and the division of responsibilities and costs in achieving it will be contested.

Recognising this heterogeneity raises questions about the institutional framework within which development research is undertaken. If both development studies and area studies are undermined by processes of globalisation that both break down regional barriers and also undermine the clear distinction between developed and developing countries, do we need special institutions for development studies at all? Why is it that we do not have interdisciplinary 'Institutes of UK Studies' and seem content to have much more focused organisations, while we retain such institutes for studies of other parts of the world? A lot of development research is, in fact, carried out by disciplinary specialists and by researchers located in specialist institutions. What do we continue to gain from 'development studies institutions'? The question is not new, of course. John Oxenham raised it in a 1980 issue of the IDS Bulletin. ${ }^{9}$

The second big issue is the relationship between development research and donor agendas. This was certainly central to the origin of development studies in the early 1960s, although it appears less so if one looks back to the late 1940s and early 1950s. This may be more problematic now. Donor agendas are perhaps less related to broader development agendas than in the past, for two distinct reasons. On the one hand, donors focus strongly on the Millennium Development Goals (MDGs) and poverty reduction. As a result, there are areas of policy and strategy that are relevant to people and governments in developing countries that lie outside donors' agendas. These issues might, however, be relevant to development research more broadly conceived, both with respect to policy questions and the country coverage of research. On the other hand, the increasing importance of donor agendas and donor financing in the poorer developing countries, particularly in subSaharan Africa, means that local and national concerns may be crouded out (co-ownership of agendas is an illusion), and development research in both North and South should play a role in offsetting the power of donors and their agendas.

Finally, there is the question of how much the reinvention of development research needs to go beyond the boundary of the current development research community. At the IDS fortieth anniversary 
conference, we were encouraged (perhaps even enjoined) to pay more attention to theory and, simultaneously to change the way society thinks about development through engagement with political and social movements (see Edwards and Harriss-White, both this IDS Bulletin). These goals are not contradictory. Both involve moving beyond shortterm policy agendas (irrespective of who is driving them - donors are not the only actors driving policy agendas) and shaping broader thinking about development. The development of theory is a prerequisite for shaping big issue agendas, while making an impact beyond the donors requires broader engagement with society (North and South, or East and West). Development research needs to engage with a broader range of actors, and part of the basis for doing this is addressing theoretical issues.

\section{Notes}

1 For example, Lenin on Imperialism and Alexander Gerschenkron on late development. The fact that such authors were 'outsiders' relative to the more advanced industrialised countries, may be a precursor of future differences in development perspectives from developed and developing countries.

2 The Prebisch-Singer argument was not unique at the time. The Polish economist, Paul RosensteinRodan's 1943 article on industrialisation in Eastern and South-eastern Europe also suggested that market forces would not be enough to take countries out of low-level equilibrium traps.

3 Every generalisation has its exceptions. There have been strands of thought and policy that have emphasised rural development, low-technology strategies, etc. Examples include Gandhian ideals of development in India and self-sufficiency in Tanzania. Even in these countries, however, these ideas were not always incorporated into national development policies.

4 A notable exception would be Samir Amin, whose 1957 doctoral thesis focused on the integration of pre-capitalist societies into the international economy and the resultant creation of underdevelopment.

5 It could be argued that elites in developing countries, such as Brazil, took the same position,
Such a reinvention must bring ideology - in the sense of contesting views about what development is and how to achieve it - back into development. Competition between development paradigms and debates over broad development strategies were in decline long before the collapse of the Soviet Union. The consequence has been that challenges to development orthodoxy have tended to shift towards the micro and local level. Contestation at this level frequently leaves macro-structures of power and orthodoxy unchallenged. As we try to reinvent development research, we would do well to look back at the broader perspectives of our predecessors and more effectively link local-level contestation with more macro-challenges to current development thinking and action.

pursuing industrialisation and policies that benefited urban areas, while leaving the rural poor not so much to their own devices as at the mercy of rural oligarchs.

6 This may suggest an abandonment of the goal of becoming modern and a switch to raising the incomes and security of people in 'non-modern' activities.

7 For example, consider the recent expressions of concern by the Labour government in the UK about the failure of welfare policies such as SureStart, to reach the most disadvantaged families.

8 While China and India are both important factors in the global economy, they are so in different ways. Clearly, the size of China's economy and its degree of openness are both substantially greater than India's, and so its direct impact on global trade in goods is much greater. India has a greater impact on services, and can be expected to have a significant impact on global governance and development thinking and policy.

9 John Oxenham (1980) 'Should Development Studies Be Taught in Britain?', IDS Bulletin 11.3, reprinted in IDS Bulletin 37.4 (September 2006) and available at www.ids.ac.uk/ids/bookshop/ bulletin/bull374.html 